\title{
Climate and Energy Governance Perspectives from a Municipal Point of View in Hungary
}

\author{
Csaba Patkós ${ }^{1, *}$, Zsolt Radics ${ }^{2}$, József Barnabás Tóth ${ }^{3}$, Enikó Kovács ${ }^{1}$, Péter Csorba ${ }^{2}$, \\ István Fazekas ${ }^{2}$, György Szabó ${ }^{2}$ and Tamás Tóth ${ }^{2}$ \\ 1 Institute of Geography and Environmental Sciences, Eszterházy Károly University, H3300 Eger, Hungary \\ 2 University of Debrecen, 4032 Debrecen, Hungary \\ 3 University of Nyíregyháza, 4400 Nyíregyháza, Hungary \\ * Correspondence: patkos.csaba@uni-eszterhazy.hu; Tel.: +36-306983788
}

Received: 4 June 2019; Accepted: 31 July 2019; Published: 2 August 2019

\begin{abstract}
European climate change objectives aim to reduce $\mathrm{CO}_{2}$ emissions, promote the spread of renewable energy sources (RES), and stimulate energy efficiency (EE). The situation of local and regional governance is crucial in the implementation of community objectives. A multi-year research project was implemented in East Hungary by the University of Debrecen and Eszterházy University. It focuses on the relevance of local communities in the formation of adequate responses to the fore-mentioned challenges. A broad range of primary data collections (questionnaires and interviews) were implemented in two rural counties of the country. The first objective was to elicit existing plans concerning RES and EE at the municipality level and to measure the rate of public participation in the elaboration of them. Secondly, the scopes of the implemented projects were examined in the target area. According to the results, local leaders seem to be committed to environmental issues, but communities rarely possess energy/climate-change plans and projects. The main motivators of project implementation are financial. Because of poor financial conditions, only EU co-financed projects are realized. As subsidies come through the national government, political factors are crucial. From a governance point of view, national and county levels are decisive, and local specialties are not taken into consideration.
\end{abstract}

Keywords: climate governance; renewable energy; municipalities; participatory development; energy poverty

\section{Introduction}

To tackle prevailing problems in the multiple environmental and socio-economic process of climate change, a multi-level activation landscape is a must. Local bodies and even individual actors are relevant participants in the implementation of climate change management in the fields of mitigation, adaptation, and raising awareness. In 2015, one article in The Guardian stated that "much of the power to reduce climate emissions lies now with cities, not national governments" [1].

In Hungary, the national government seems to be devoted to following a sustainable climate and energy management pathway, as the country has signed relevant international agreements and elaborated national documents of energy transition and climate change policy. The National Energy Strategy (77/2011. (X.14.)) was accepted in 2011 and declared the need for a change in energy structure. In order to achieve its measures of energy efficiency (EE), low carbon-dioxide energy production and transport and the spread of renewable energy technologies must prevail.

The aim of the recent study is to give insight into the situation of EE programs and renewable energy sources (RES) investments of some rural regions in Northern and Eastern Hungary from a municipal point of view. 
Climate change and energy transition issues are depicted as phenomena affected by constant innovation and governance actions [2].

\section{Literature Review}

Beyond technological change and advancement, a broad range of raising awareness should be fulfilled (from school-type teaching to non-formal education), shifting all generations towards an environmentally conscious pathway. Increasing the related knowledge in consumers and producing a proper behavior are key elements in the establishment of a more sustainable future [3].

In a longer period of time, it would be relevant to put emphasis on environment- and community-oriented interests. The role of institutions of public administration, institutions, and infrastructure is crucial in this process. Municipalities (in Hungary, even the smallest settlements can have their own municipal body; in the article, two terms-settlement and municipality-are used interchangeably) must have a decisive function in the implementation of energy-conscious settlement management and development [4]. For example, Sustainable Energy and Climate Action Plans (SECAPs) are useful tools to concentrate such efforts of municipalities [5].

Climate change is one of the main challenges of our age. A broad spectrum of institutions and agents—-from the global level to the local level—feels it is their job to deal with these problems. A "Cambrian explosion" of climate governance can be seen, as it has become complex, fragmented, and decentralized. [6] Climate governance has to be extended to adaptation, mitigation, and raising awareness, too; additionally, complex coordination mechanisms should be included [7].

Local-level energy efficiency and renewable energy harvesting can help to tackle challenges of climate change, but it is a significant task for nation states to give municipalities legal and financial support opportunities. [8] Local self-governments usually possess plenty of buildings. The energetic modernization of these, on the one hand, is a great tool to support national climate and energy objectives, and on the other hand, the promotion of local initiatives may help to establish real sustainable development [9]. Successful local climate management may generate benefits [10], but municipalities with financial strains are likely to miss such programs [11].

At the beginning of the 1990s, the Hungarian system of local self-governments was created following European examples and guidelines. Local municipalities-even the smallest ones-became relevant actors of the national socio-spatial landscape. Beyond carrying out central and national orders and objectives, theoretically, they are allowed to create their own plans and projects of sustainability [12,13].

In principle, municipality-led complex renewable energy sources (RES) and EE projects tailored to local conditions could be implemented using place-sensitive resources and technological and organizational solutions. These autonomous and innovative projects may be managed either individually by local self-governments or by micro-regional voluntary co-operations. This local model may help local economic development and job creation, including social employment as well.

In local strategies, climate change mitigation seems to be a more emphasized part, and renewable energy resources are indispensable parts of it. Together with renewable energy use, it works as a fashion of recent days. As George W. Bush said, "We are all environmentalists now" [14]. Transition methods are vital to realizing these issues. As there are many different possible pathways, experiments in climate governance and energy transition are crucial $[15,16]$.

These can be interpreted as innovations [17]. Anguelovski-Carmin [18] (p. 169) state:

"Cities in both the global North and South are testing new institutional arrangements and experimenting with adaptation and mitigation policies, plans, and processes as they seek to develop and advance their climate agendas".

At the same time, this green transition is relatively new, and, additionally, municipalities often lack relevant resources and expertise to implement well-embedded steps. As Keskitalo et al. [19] (p. 1) state: 
"Climate change has not yet been sufficiently integrated into the state regulative structure of legislation and policy-making."

Consequently, there is no established way of solution, and it might be said there is a situation of an innovative "must". Innovations hide in the socio-economic background of renewable energy solutions and climate management measures [20].

Innovation can be interpreted in multiple ways, as technological, organizational, or social ones can be differentiated. Freeman, in his explanation of innovation, emphasizes the relevance of background systems:

"... systems of innovation are networks of institutions, public or private, whose activities and interactions initiate, import, modify, and diffuse new technologies." [21] (p. 1)

According to Malerba, innovation regimes have three interrelated sub-systems. Firstly, technological components and related competencies are mentioned. Secondly, different participants of networks contribute to the functioning of it. Finally, systematic behaviors and rules give an institutional framework to the whole process. Among actors, producers, technology providers, and users, government agencies, municipalities, think tanks, and non-government organizations can be found [22].

Concerning technology, Schumacher introduced the phrase, "non-violent economics and technology", referring to technologies compatible with local socio-economic and ecological conditions [23]. Accordingly, locally introduced climate management and renewable energy technological solutions should not only be effective, sustainable, and state-of-the-art but should fit to local circumstances as well. The non-violent character can be extended to existing local capabilities of proper project implementation too.

Changes leading to energy transition occur in a complex socio-technological regime simultaneously in five dimensions: socio-cultural, policy, science, technology, user, and market (Figure 1). A broad partnership of actors is supposed to be important in the realization of such projects. As Elbe et al. stress, value-added partnerships integrating economic, government, and non-governmental organization (NGO) sides are proper ways of renewable energy-based project planning and implementation [24]. With this multi-partner angle, there is a possibility to integrate bottom-up and top-down approaches [25].

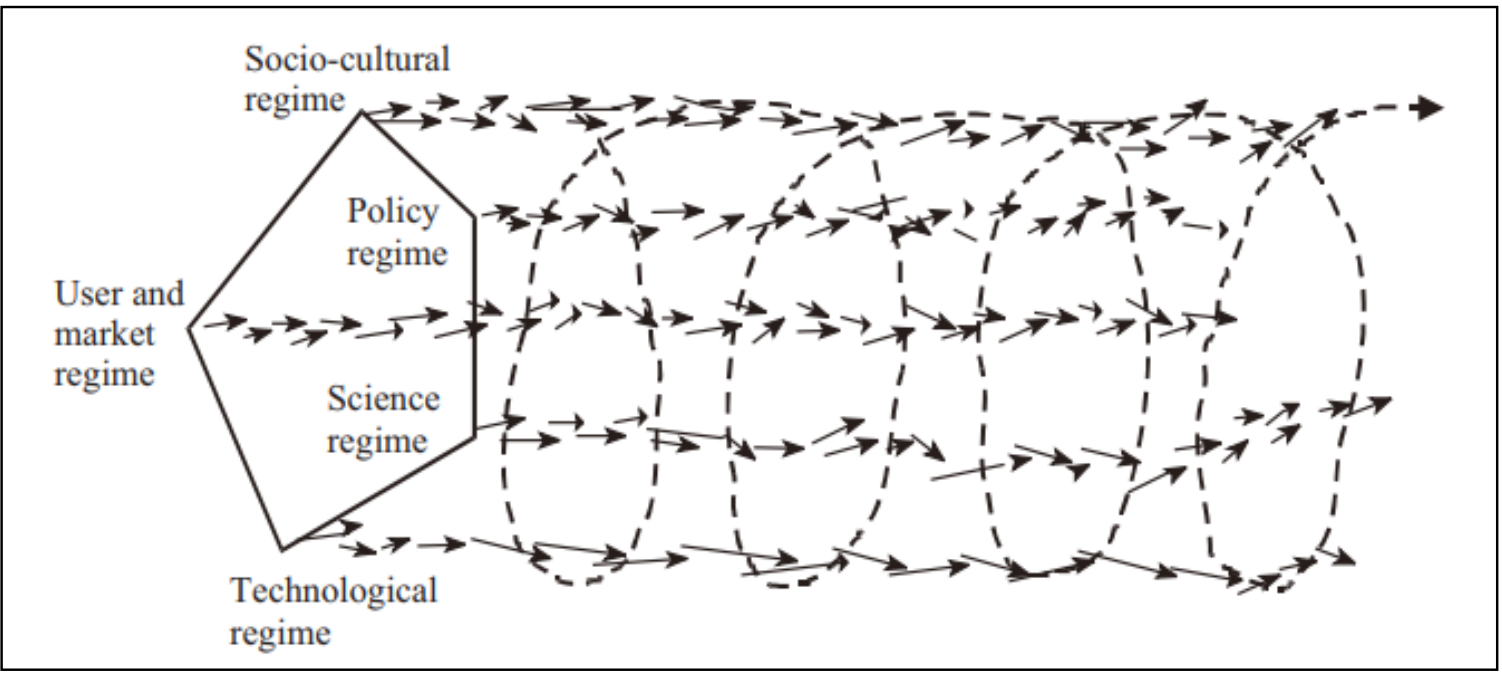

Figure 1. Coexistence of different currents in a socio-technological regime [24].

This multi-level perspective integrates the issue of power relations. Grin et al. differentiate three types of powers [26]:

- Relational-different competencies of agents result in altering achievements in experiments; 
- Dispositional-the position of different actors in the system assigns results;

- Structural—steady relations of domination and legitimization occur in slowly changing circumstances.

A similar structure was created by Schönberger, differentiating overarching measures (local energy plans, objectives, integration into networks of energy-oriented municipalities), the individual behavior of the local administration, or the effect of the reaction of other actors through local regulations, either by the production of energy or by joining consciousness rising of citizens [27].

The role of municipalities in climate and RES governance raises relevant questions concerning the types of participation of local-level agencies. A complex municipal climate governance analytical grid was elaborated by Scanu and Cloutier [5]. This frame was used by us during the research as a conceptual framework. Through their system, municipal involvement in climate governance $(\mathrm{Cg})$ can be divided into two parts.

This framework, on the one hand, differentiates the motivation of the participation of municipalities in climate change. Four various factors were listed that may contribute to local decision-making. There are some factors coming from the characteristics of the given site. Ecological considerations include geomorphological and climatic conditions. Economic factors contain funds and subventions as well as growth opportunities. Institutional issues can be decisive, such as normative frameworks (law or strategies relating to climate changes). Political will (central and municipal) is also important to tackle challenges relating to climate change. Additionally, some social groups are more exposed to negative effects (the elderly, babies), and their interests can be taken into consideration to different degrees. In the case of each and every factor, local interpretation and knowledge is a key mechanism [5].

On the other hand, the conceptual framework answers the question of how local climate governance occurs. The three main types of climate change measures are adaptation, mitigation, and raising awareness. These steps can be very successful in the case of the existence of different planning instruments, such as adaptation strategies, mobility plans, greenhouse gas (GHG) reduction concepts, and municipality master plans. Strategies and activities may be extended to different sectors, such as energy, transportation, water supply, waste management, etc.

Beyond these types of actions, the way of governing is an interesting point as well. Related adjudications may be based on the principle of self-governance, where local initiatives dominate the whole process, including planning, finance, and implementation. A different situation occurs when public-private partnership projects and awareness campaigns are invoked. The third way is named "governing by provision", including projects such as infrastructure improvement or recycle programs. Finally, municipalities have the right of legislation, such as the setting up of building restrictions in certain areas or the blocking of some economic activities in sensitive zones of the settlement [5]. During these points, different actors can be included, such as participants of the official government, members of the civil society (NGOs), private sector organizations, or even intellectual spheres (universities, colleges) $[15,28]$.

Urban municipalities seem to be over-represented in climate change management processes, and bigger cities tend to frame local climate policies to a greater extent $[29,30]$. Their intensive involvement can be explained on the one hand by their demographic (high population density), climatic (urban heat island), or physical (high built-up ratio) character [31]. On the other hand, urban nodes are more liable to connect inter-municipal networks and to use innovative methods, making their climate management efforts more effective [32,33]. According to Hakelberg, the role of transnational municipal networks is decisive in the success of climate change issues [34,35].

Rural areas are very often sparsely populated zones with narrow service roles and modest financial resources; additionally, their networking and innovation activities are generally more modest [36].

In the literature, there are some country-wide research examples focusing on the role of municipalities in climate change management. In Canada, municipalities with populations of more than 10,000 inhabitants were asked by a questionnaire with a main focus on barriers of successful climate change response [37]. 
A research project aiming to map all municipalities of Norway argued that local climate change management efforts are reactive, as generally areas suffering from extreme weather events invest in climate change adaptation [38].

Wejs [39] conducted a survey with eight Danish municipalities and indicated three types of institutional behavior of climate change planning. This investigation underlines the relevance of local networks in contrast with international ones.

Eckersley [40], in his paper, compared the climate change policies conducted by one German and one English city. It may be concluded that the national frameworks of central-local relations define the successful local climate governance methods.

\section{Materials and Methods}

\subsection{Research Objectives and Methodology}

The main aims were to draw a picture on the level of their knowledge on renewable energy and to show how they perceive climate change locally. The exploration of any future ideas or existing plans locally tackling challenges of climate change was an issue. An additional objective was to highlight the existing EE and RES harvest projects at different settlements. Finally, the patterns of local social participation were examined. A quota sampling was implemented in two Eastern and Northern Hungarian counties to secure the integration of bigger and smaller municipalities as well. In aggregate, 29 settlements were picked from a total of 203 of the two counties. The main research question was as follows:

- What kind of governance patterns can be observed concerning these programs and projects? (Who participates in planning and implementation locally? Beyond local participants, which territorial levels and institutions take part? What forms of decision-making can be distinguished?)

In order to get a clearer view on the existing socio-economic circumstances of the target area, some technical unraveling questions were asked:

- What are the main socio-economic parameters of the chosen area?

- What level of knowledge do municipal leaders have about renewable energy sources?

- Are there existing local climate management plans concerning local, micro-regional, or county levels?

- How do local prominent persons perceive the effects of climate change?

- What type of projects were implemented locally in RES and EE in the last several years?

At first step, a short socio-economic introduction was delineated to point to the main phenomena of the target area. Basic demographic, economic, and infrastructure data were collected from the open database of the Hungarian National Statistic Authority (KSH-http://www.ksh.hu/teruleti), and, additionally, some information was gained from the Hungarian Database of Spatial Information (TEIR-www.teir.hu). Through this interpretation, sample settlements were placed on the Hungarian national socio-economic map.

Due to the complex set of objectives, the qualitative research methods included semi-structured, in-depth interviews taken with members of the local elite by experienced senior researchers of the project team. The interview guide is enclosed in the Appendix A of the article. The interview was divided into four chapters. Firstly, a short self-introduction was required, supplemented by some basic information about the settlement. In the main part, issues on climate change and renewable energy use were asked, and finally, related future plans were enquired (see Appendix A). Among the prominent persons, firstly, local municipality leaders [mayors, notaries (a notary is the head of the local executive power, his role is to co-ordinate local administration financially, legally, and operatively. He is the first legal control level over the mayor and the municipal body)] were approached, and secondly (in case of unavailability of the former actors), school managers or NGO directors were asked. In total, semi-structured, in-depth interviews were taken with 29 local leaders. 


\subsection{A Short Description of the Case-Study Areas}

The research was implemented in two NUTS 3 spatial units in Hungary-Heves and Hajdú-Bihar counties-where a total of 29 settlements with diverse socio-economic conditions were examined (Figure 2). Among them, two cities with county rights-cities that exercise the rights of a county within its boundaries-were picked. In general, they have the best material background as well. Some of them were small towns with fewer rights, and the majority comprised small villages with the least administrative power and minor financial resources.

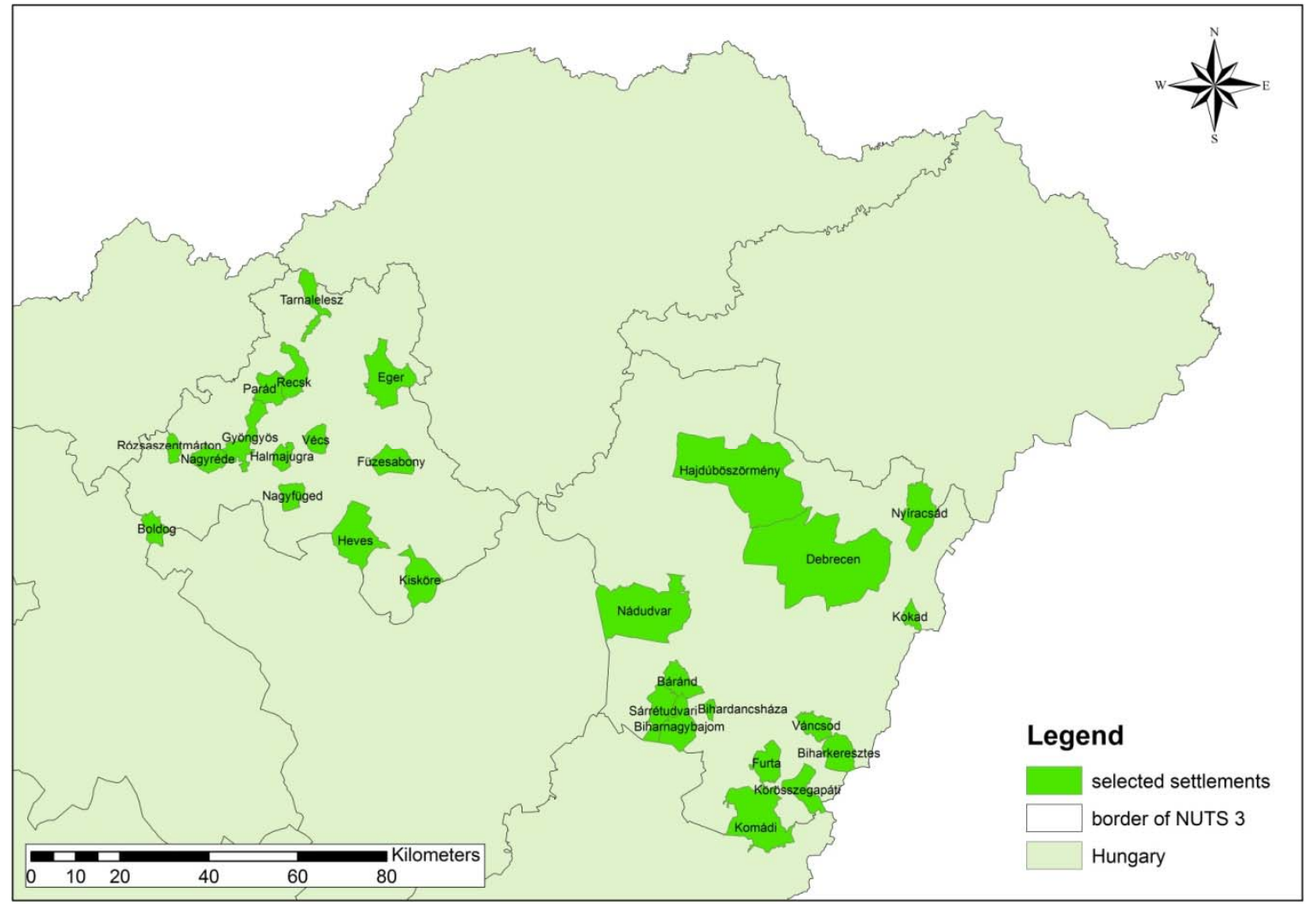

Figure 2. The geographic scope of the research (authors' edition).

The study area represents the main attraction zones of the two universities. They belong to the North Hungarian and the North Great Plain Regions. Although both regions belong to the least developed areas of Hungary, there are some more advanced urban zones (Debrecen and Eger) as well, where the socio-economic development level is above the national average. Concerning the population, information technology (IT) accessibility, education level, and employment conditions, the chosen settlements are diverse in order to represent the national situation. In the Hungarian system of governance, municipalities, as legitimate units, have elected bodies, may tax local activities, and can arrange local public affairs autonomously. Bigger towns and cities have almost the same rights-there is no subordinate relationship among them. The 19 Hungarian counties have their municipal bodies, but they have no right to control village or town municipalities. Counties help the government to plan and realize spatial development programs. The national government indirectly controls municipal activities through the system of public administration, but its objectives can be bulldozed directly through financial tools as well (Figure 3). 


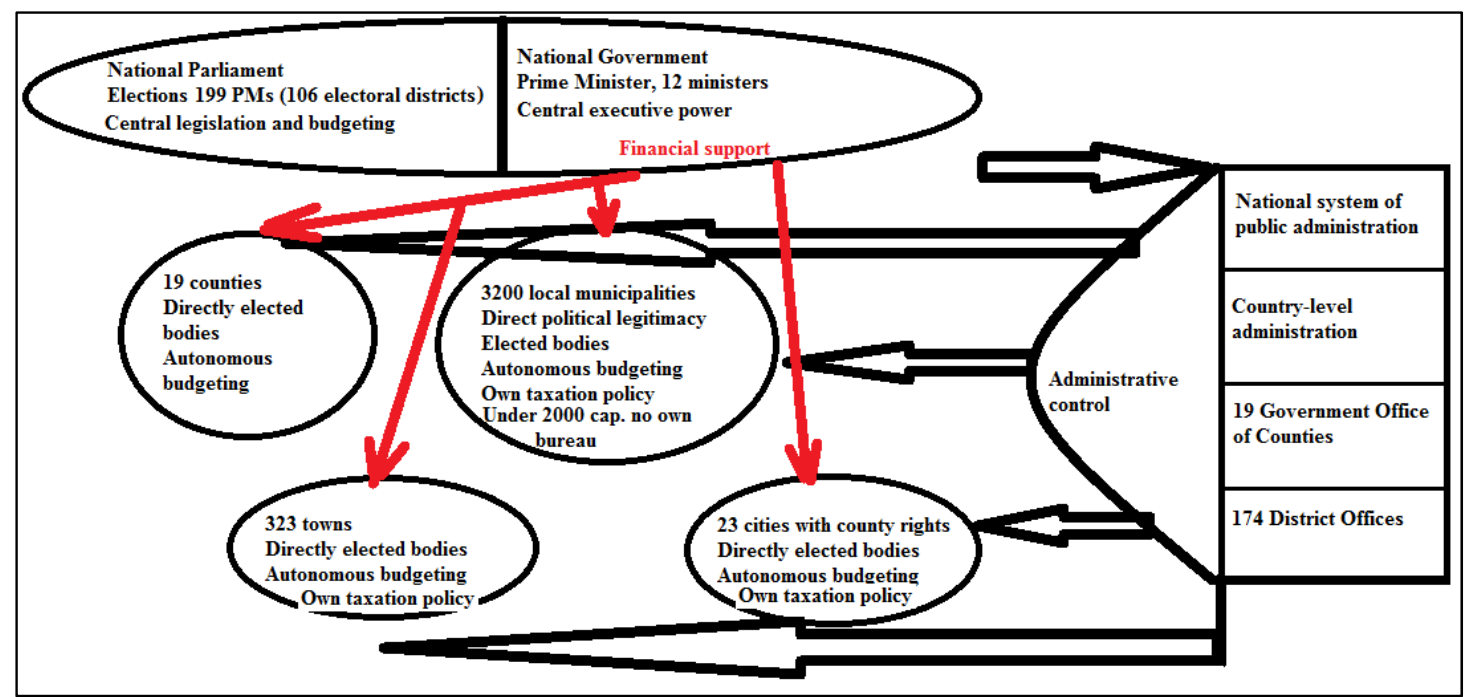

Figure 3. Elements of the Hungarian system of government and governance (authors' edition).

Relative to the year 2000 as the base in population change in the chosen settlements, it can be seen that, in small villages (under 1000 persons), the decrease is drastic (-15\%), and in bigger towns (between 1000-100,000 persons), the decrease is significant ( -3 to $-7 \%$ ). Decrease is a national trend as well $(-3 \%)$, while in the European Union, the rate is $+5 \%$ (Figure 4$)$. Compared with the national rate, the city of Debrecen is in a better situation with a $2 \%$ decrease.

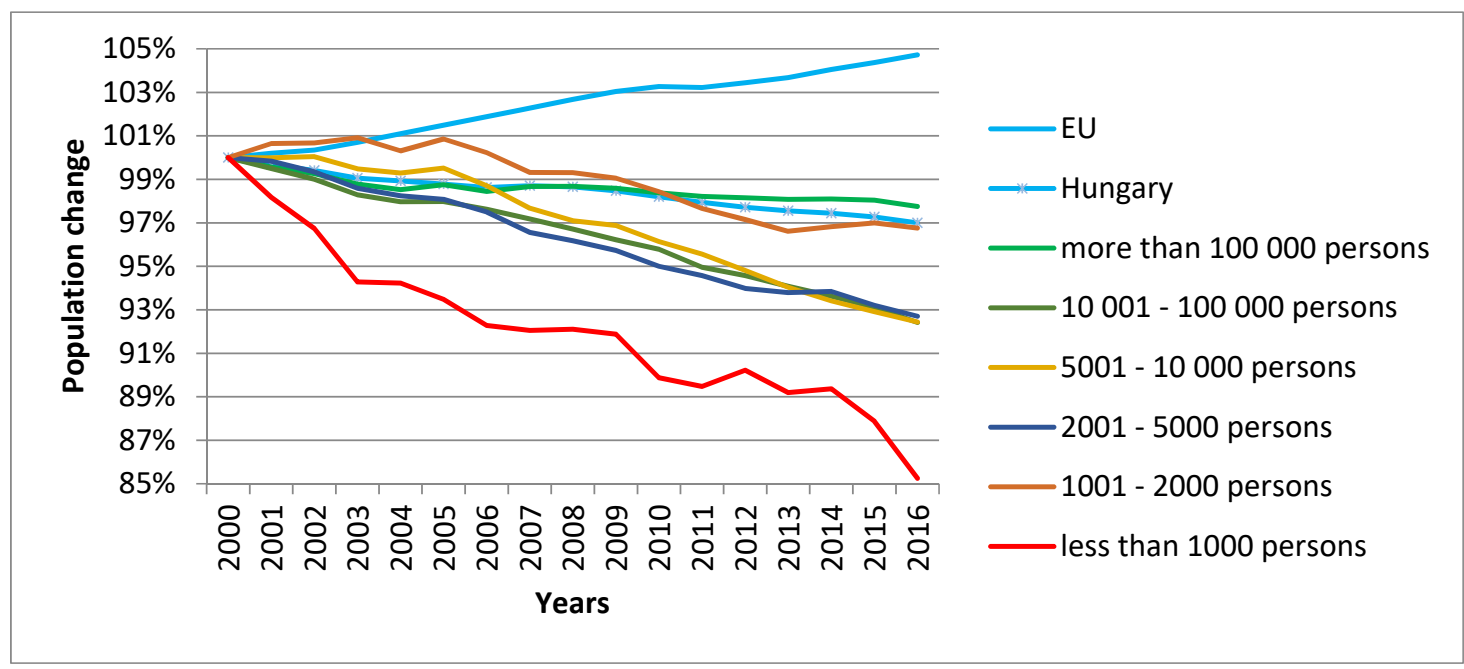

Figure 4. Population change compared with the value of the year 2000 in a population number breakdown [authors' edition based on the Hungarian National Statistic Authority (KSH) database].

Concerning the level of education (Figure 5), the situation is similar in Hungary. Smaller villages have a higher rate of low-educated persons, and higher education is rare in these settlements.

The disadvantage of smaller villages in the case of television and Internet access is prevalent. (Figure 6). While in Hungary, the average number of homes with a television network is 251 per 1000 persons and the average number of Internet connections is 281 per 1000 persons, in settlements with fewer inhabitants, these values are much lower. In villages with fewer than 1000 inhabitants, these values are 81 and 158, respectively, which is a dramatic gap compared to the national average. 


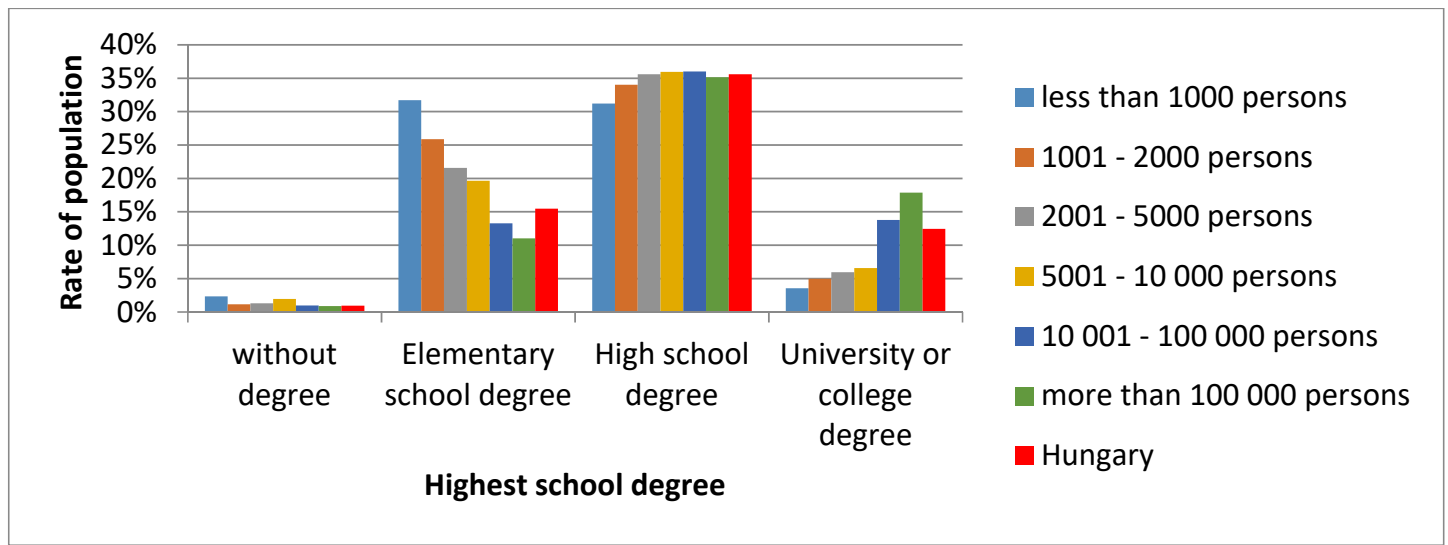

Figure 5. The highest completed level of education among persons aged over seven years old; breakdown by population categories (percentage-wise) (authors' edition based on KSH database).

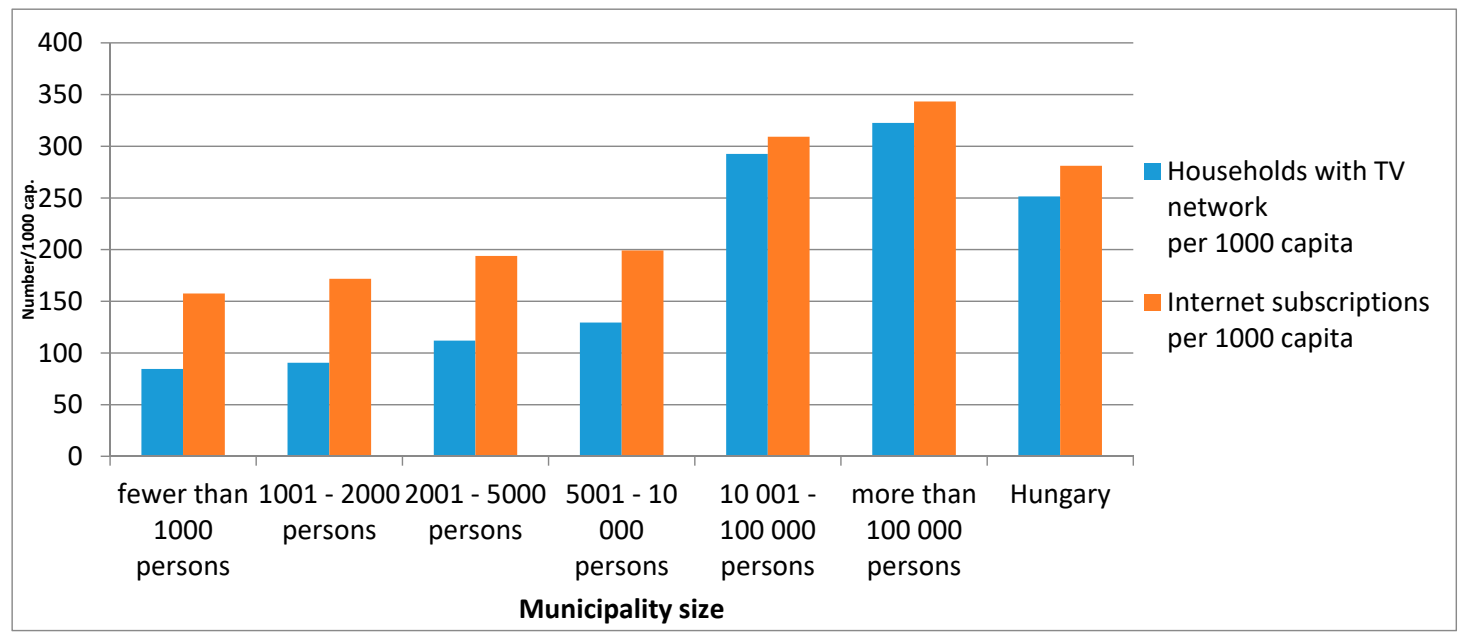

Figure 6. The number of households with television and Internet access per 1000 capita by population categories (authors' edition based on KSH database).

Settlement size seems to be a decisive factor in the case of domestic income per capita as well. Based on the 2016 data of the TeIR (Országos Területfejlesztési és Területrendezési Információs Rendszer-National Spatial Development and Land-Use Planning Information System), the per capita domestic income in Hungary is 180,000 HUF per month. Compared to this, among the examined settlements, one can find a city (Debrecen) with a domestic income of 192,000 HUF per month, but in the village (Bihardancsháza), it is only 85,000 HUF per month.

If the gross domestic income per taxpayer would be divided into categories by the size of settlements (Table 1), a ranking similar to the former ones could be set up, where smaller population means a disadvantage.

In the case of unemployment, the variation is great too. The national rate was $5.1 \%$ in 2016 . By comparison, in the examined settlements, it varied between 1.95\% (Nagyréde) and 14.42\% (Halmajugra). However, in this case, an unambiguous range could not be created, as the rate was dispersed between $4.6-7 \%$ (Table 2).

Concerning age structure (Table 3), an aging population can be seen in Hungary. In the target area, smaller settlements have more young ( $0-29$ years old) inhabitants, but the elderly (above 65 years) persons are present there in a higher ratio as well. 
Table 1. The degree of monthly gross domestic income per taxpayer by population categories.

\begin{tabular}{cc}
\hline Population (Persons) & Monthly Gross Domestic Income per One Taxpayer \\
\hline under 1000 & 114,601 \\
$1001-2000$ & 131,924 \\
$2001-5000$ & 136,906 \\
$5001-10,000$ & 141,570 \\
$10,001-100,000$ & 168,792 \\
above 100,000 & 191,626 \\
Hungary & 180,326
\end{tabular}

Source: Országos Területfejlesztési és Területrendezési Információs Rendszer-National Spatial Development and Land-Use Planning Information System (TeIR) 2016.

Table 2. Unemployment rate by population categories.

\begin{tabular}{cc}
\hline Population (Persons) & Unemployment Rate \\
\hline Under 1000 & $6.43 \%$ \\
$1001-2000$ & $7.00 \%$ \\
$2001-5000$ & $6.03 \%$ \\
$5001-10,000$ & $5.49 \%$ \\
$10,001-100,000$ & $4.60 \%$ \\
Above 100,000 & $5.00 \%$ \\
Hungary & $5.10 \%$ \\
\hline
\end{tabular}

Source: KSH-TSTAR. (Spatial Statistical Collection of the Hungarian Central Statistical Office)

Table 3. Age groups in the target area and in Hungary by population categories.

\begin{tabular}{lcccccccccc}
\hline $\begin{array}{l}\text { Population } \\
\text { (Persons) }\end{array}$ & $\begin{array}{c}\mathbf{0 - 1 4} \\
\text { Years }\end{array}$ & $\begin{array}{c}\mathbf{1 5 - 1 7} \\
\text { Years }\end{array}$ & $\begin{array}{c}\mathbf{1 8} \\
\text { Years }\end{array}$ & $\begin{array}{c}\mathbf{1 9} \\
\text { Years }\end{array}$ & $\begin{array}{c}\mathbf{2 0 - 2 9} \\
\text { Years }\end{array}$ & $\begin{array}{c}\mathbf{3 0 - 3 9} \\
\text { Years }\end{array}$ & $\begin{array}{c}\mathbf{4 0 - 4 9} \\
\text { Years }\end{array}$ & $\begin{array}{c}\mathbf{5 0 - 5 9} \\
\text { Years }\end{array}$ & $\begin{array}{c}\mathbf{6 0 - 6 4} \\
\text { Years }\end{array}$ & $\begin{array}{c}\mathbf{6 5 - X} \\
\text { Years }\end{array}$ \\
\hline Under 1000 & $15.76 \%$ & $3.62 \%$ & $1.54 \%$ & $1.54 \%$ & $14.62 \%$ & $11.00 \%$ & $15.96 \%$ & $10.87 \%$ & $5.63 \%$ & $19.45 \%$ \\
$1001-2000$ & $17.08 \%$ & $3.67 \%$ & $1.20 \%$ & $1.16 \%$ & $13.32 \%$ & $13.30 \%$ & $13.79 \%$ & $12.05 \%$ & $6.85 \%$ & $17.58 \%$ \\
$2001-5000$ & $14.70 \%$ & $3.44 \%$ & $1.15 \%$ & $1.15 \%$ & $12.66 \%$ & $13.58 \%$ & $14.82 \%$ & $13.02 \%$ & $7.30 \%$ & $18.18 \%$ \\
$5001-10,000$ & $14.46 \%$ & $3.53 \%$ & $1.16 \%$ & $1.12 \%$ & $13.67 \%$ & $13.60 \%$ & $15.15 \%$ & $13.01 \%$ & $7.38 \%$ & $16.93 \%$ \\
$10,001-100,000$ & $13.59 \%$ & $3.00 \%$ & $0.98 \%$ & $1.02 \%$ & $11.76 \%$ & $14.19 \%$ & $15.75 \%$ & $12.49 \%$ & $7.82 \%$ & $19.40 \%$ \\
Above 100,000 & $13.64 \%$ & $2.65 \%$ & $0.95 \%$ & $0.89 \%$ & $12.53 \%$ & $15.71 \%$ & $16.31 \%$ & $12.22 \%$ & $7.36 \%$ & $17.75 \%$ \\
Hungary & $14.35 \%$ & $2.92 \%$ & $0.98 \%$ & $1.02 \%$ & $12.32 \%$ & $14.60 \%$ & $16.02 \%$ & $12.35 \%$ & $7.36 \%$ & $18.07 \%$ \\
\hline
\end{tabular}

It may be concluded that the majority of the examined areas are typical ones, essentially lagging behind with an aging population and shrinking settlements. Statistical analysis showed a socio-economic performance below the national average. In these circumstances, the exploitation of local resources should be far more relevant to create a sustainable development pathway. A stark difference can be found between smaller villages and more populated towns in terms of social and economic conditions.

\section{Results}

\subsection{Knowledge and Motivation on RES and Climate Change}

During the interviews, respondents were asked to list things that came to mind about renewable energy sources. A word frequency graph was created from the text of interviews concerning knowledge on renewable energy sources (Figure 7). Solar, water (hydroelectric), and wind were the most familiar ones. It is worth mentioning that, for many interviewed persons, different technological solutions were equal to RES. This might be explained by an over-technologized view of RES issues compared with social, ecological, and governance considerations. Although biomass is one of the most frequently used renewable energy sources in the Hungarian countryside, it is a relatively rarely mentioned type. Presumably, the word itself is rarely used, and this is also proved by the fact that different kinds of 
biomass are present in the list in high numbers. One can see that even non-renewable nuclear energy was referred to by someone. It can be seen that conceptual frameworks are various and sometimes contradictory and distorted.

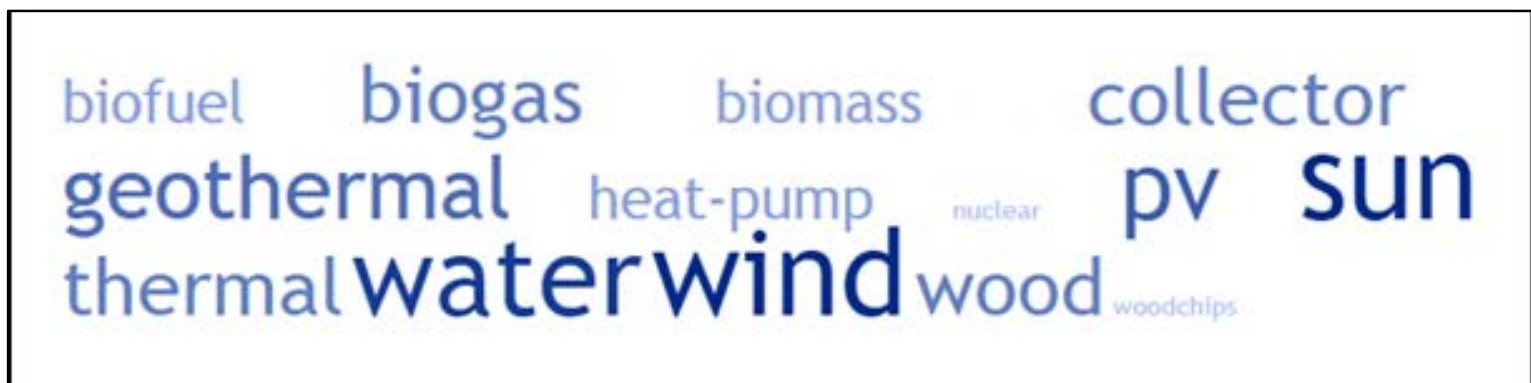

Figure 7. Associations of local prominence on renewable energy sources (authors' edition).

In the following, the previously mentioned municipal climate governance analytical grid is used to present the results.

In collecting answers in response to the question of why municipalities care about climate change and renewable energies, in some cases, ecological considerations can be found. Mostly in Northern Hungary (hilly landscape), some settlements suffer from flash floods caused by extreme heavy rainfalls. In this region, some valley-based villages are endangered by smog coming from anachronistic and air-polluting residential heating habits.

"A lot of persons—-mainly children and the elderly—suffer from asthmatic diseases, probably caused by air pollution." (One village mayor)

Some of the answers refer to the extreme poverty of the Roma minorities in many settlements of the target area:

"Local poor and Roma people have no chance to use modern technology of air conditioning.

They suffer from heat waves and it causes health hazards among them." (Local NGO representative)

In many cases, climate defense measures are justified by their side-effects. With better building insulation and more effective public lighting units, local communities can reduce energy costs. While it is a general point of view, on the contrary, job creation as a benefit is rare in the case of settlements of the research.

\subsection{Institutional Background}

From an institutional point of view, only bigger towns were found to have their separate institutions of climate management and energy efficiency. They also have written energy and/or climate change strategies. Many local politicians declare climate change as an important issue but as something "out there".

"We are committed to fight against climate change, but our village is too small ..." (A village notary)

All of the interviewed see climate change as a danger and a global threat. Even some social strata are felt to be more exposed to negative consequences.

"I worry about the future of the youth including my own grandsons!" (A local mayor)

"Elderly persons suffer most from more frequent summer heat waves ... " (A local NGO leader) 
The ways of participation in climate and RES governance are quite diverse among the examined settlements. Climate-sensitive planning is rather rare in the target area, and only bigger towns have some kind of energetic/climatic plans [SEAP (SEAP: "Sustainable Energy Action Plan, SECAP (SECAP: "Sustainable Energy and Climate Action Plan". Both documents are propagated by the Covenant of Mayors to involve municipalities more actively into the fight against climate change.), etc.]. In Hungary, as of recently, the county is the only sub-state territorial unit to have functions of planning and regional development. One of their functions is to help these activities of municipalities. County-level climate planning has been implemented in the last months, and settlements had the possibility to join this process. The majority of responding municipalities knew this county-level process, and many of them participated in it actively. Unfortunately, the smallest ones did not even hear about these.

Concerning climate or energy planning, it may be seen that only bigger municipalities handle it as their own duty. On the map, Hungarian municipalities joining the initiative of the Covenant of Mayors are visualized. It is obvious that only a few of them entered this international initiative- unfortunately, just one of them (Debrecen) was included in the research (Figure 8.)

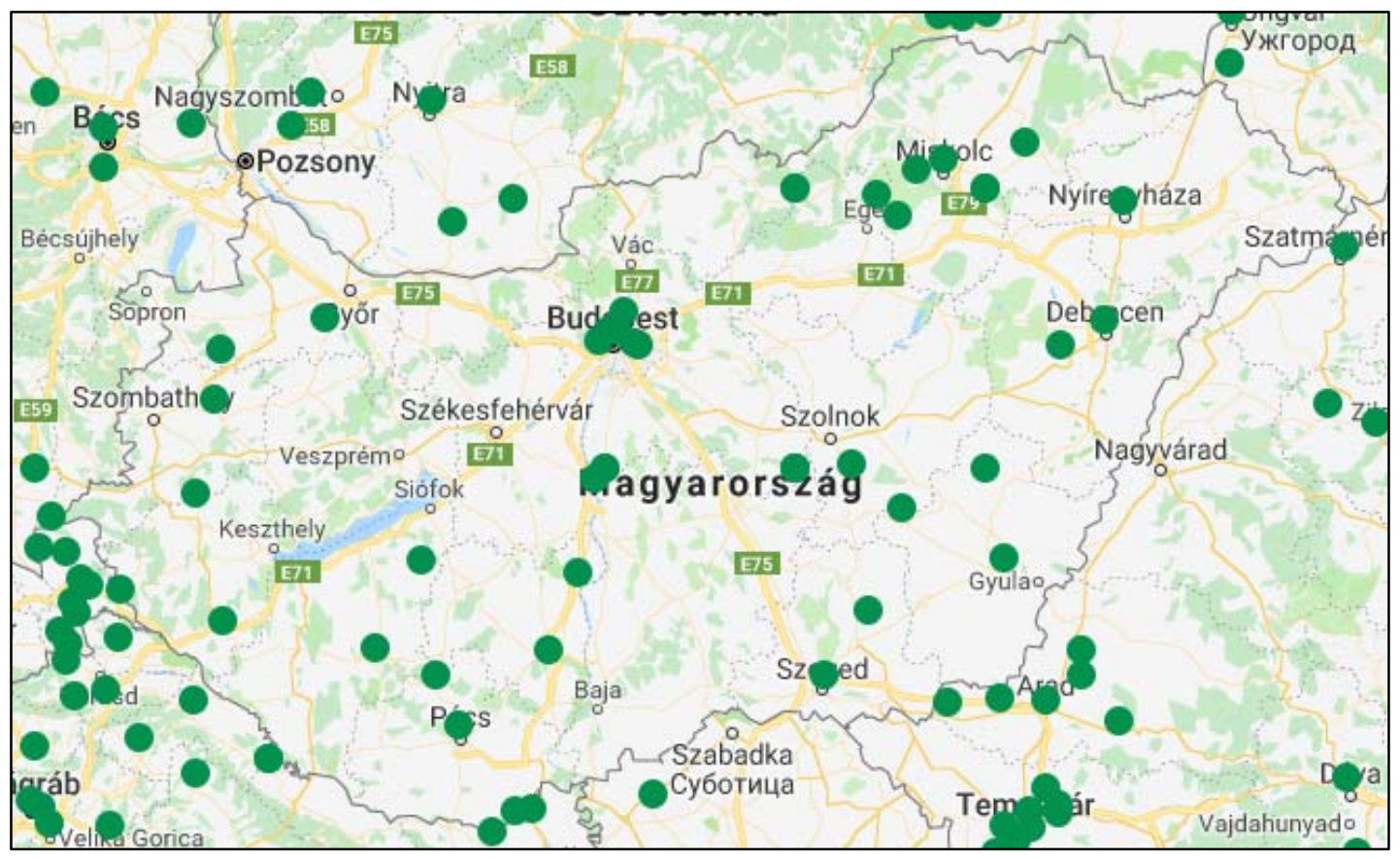

Figure 8. Membership of Hungarian municipalities in the Covenant of Mayors European Initiative in 2018 (Source: https://www.covenantofmayors.eu).

The mode of attendance in climate governance can be manifested in tangible projects and programs. One of the most popular projects is the energy-efficient retrofitting of public buildings. It usually means the replacement of old windows and doors with more effective and up-to-date plastic ones or the insulation of external walls and roofs of buildings. The majority of municipalities have already realized some projects. The main benefit for them is the improvement of energy efficiency in public buildings.

In many cases, more efficient heating systems are installed in public buildings. Very often still, fossil fuel is used for heating, but more modern and efficient facilities are equipped as well (condensation gas furnaces). Among renewable energy types, the most frequently used one is solar. The roofs of public buildings are very often covered by photovoltaic (PV) cells and solar collectors, even in smaller villages.

The modernization of street lighting [through the use of light-emitting diode (LED) technology] is widespread, though because of some home policy scandals, it seems to be a less popular issue among municipalities [41]. 
Only bigger settlements have already implemented or plan to realize projects in green transportation, for example, in the form of tram-line development or the installation of e-car chargers [42].

As can be seen from the word frequency graph (Figure 9), the majority of local projects are related to energy efficiency, the use of insulation, and the installation of new boilers (sometimes traditional but more efficient gas boilers).

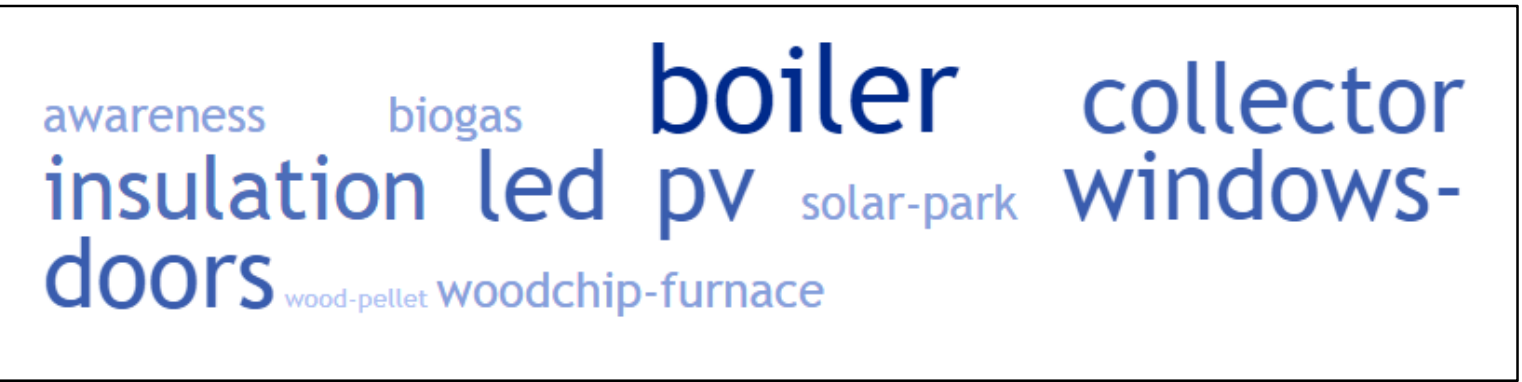

Figure 9. A word frequency graph on locally implemented energy efficiency (EE) and renewable energy resources (RES) projects (authors' edition).

Municipalities are entitled to legislate local society and economy compatible with national law. The regulation of environmental issues is such an area as well. However, respondents recognize the relevance of sustainability and the importance of local steps towards this, and they rarely use local authority rights.

"I know poor persons using plastic waste for heating and it causes serious smog and respiratory problems, but we are unable to use effective tools to prevent it. Maybe central government could make the needed steps." (A village mayor)

During the interviews, a great emphasis was put on the detection of the way of planning and implementation of RES and climate management projects. To illustrate this, a draft of the Hungarian climate governance system was drawn (Figure 10). The illustration was compiled in conformity with the answers of respondents.

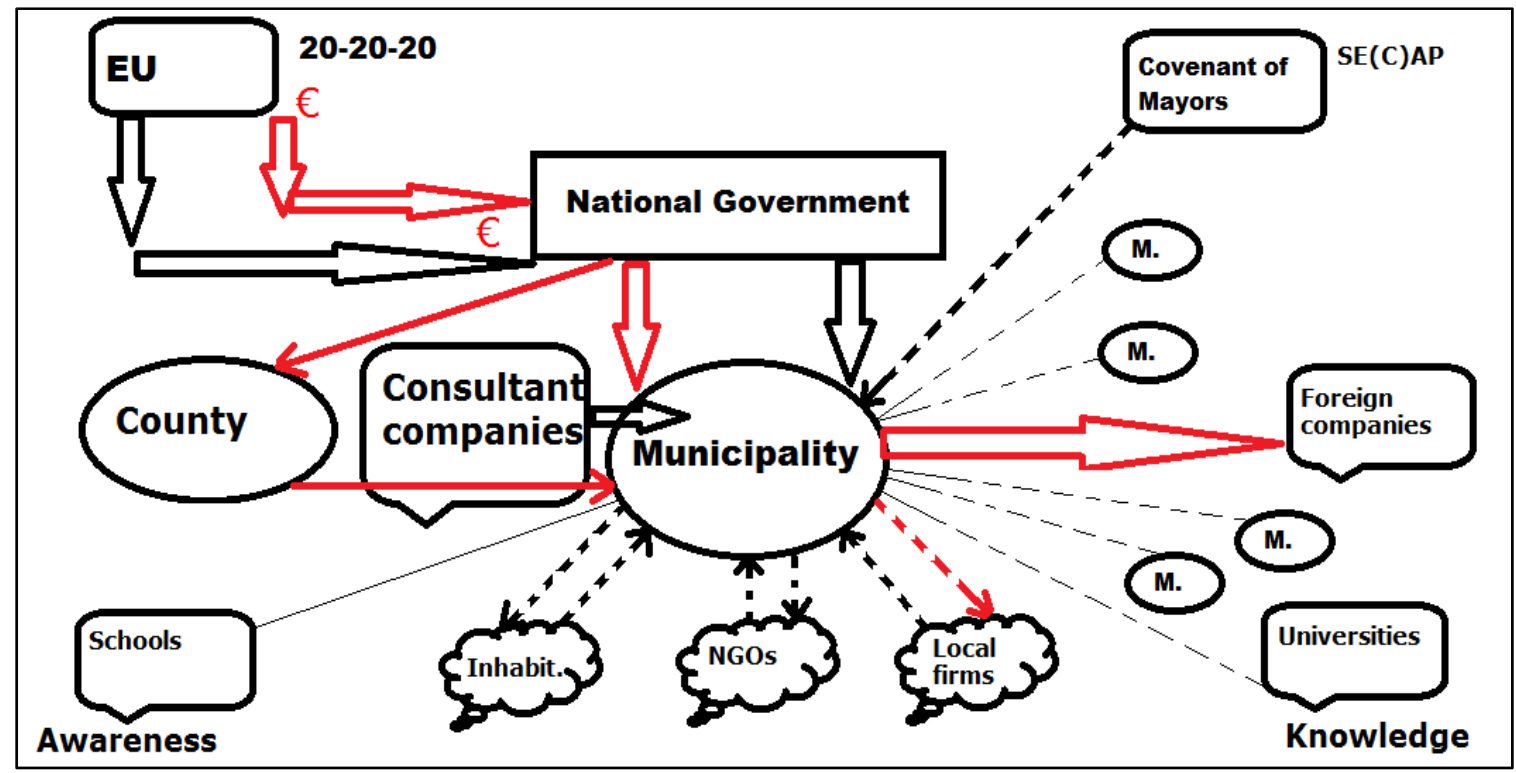

Figure 10. The system of RES and climate governance from a municipal point of view (authors' edition). 
The municipality is in the center, and it is affected at different levels. On the top of multi-level governance, the European Union (EU) can be found through its directives, initiatives, and financial resources. It is trying to motivate municipalities towards a more sustainable way of existence. In general, this influence is indirect, as the national government and counties play transmitting roles. Additionally, in Hungary, an extra level can be found in the form of an opaque network of consultant companies. According to many respondents, these enterprises are trying to monopolize the planning and the implementation of all local development projects. Generally, they cooperate with national- and county-level politicians, and direct political influence can be indicated in their activities. Through these channels, some parts of the EU aid are absorbed by a grey network of non-local companies. Unfortunately, local municipalities rarely have their own team of experts, and mainly the smaller ones are exposed to this external expertise.

"County representatives attracted our attention to apply for this or that call, because 'That is devoted to our municipality'. Additionally, they sent proposal writers and a manager. All details were determined by them. And of course we won." (A village mayor)

Centralization is one major character of this system, and unfortunately, neither in planning nor in implementation and monitoring are local interests taken into consideration. In this way, municipalities are unable to cooperate and to involve local inhabitants, NGOs, and enterprises, thus the principles of partnership and subsidiarity are damaged.

Local schools and universities might play an important role in innovation and in raising public awareness. Climate change can be added as well. Unfortunately, now the Hungarian system of education is becoming more and more centralized, and their bonds towards municipalities are weakening.

Inter-municipal cooperation could be very relevant in some RES projects, such as biomass utilization. Since 2010, these micro-regional connections have been dying, and centralization has become the main organization source.

"Yes, the micro-region once was a great platform of co-operation. Some eight years ago it started to decline. Now we are rivals with our former friends. We are fighting for the same central money support." (A village notary)

\section{Discussion}

Although climate change is a global issue, local regards are crucial for mitigation, adaptation, and raising awareness as well- "approaches with participatory elements offer multiple potential benefits over purely top-down approaches" [43]. Specialized local strategies could be of primary importance, but, according to the literature, the overvaluation of the local level can lead to the so-called "territorial trap" [44], where the effectiveness of the used measures becomes limited. According to the research, among Hungarian municipalities, the penetration of bottom-up initiatives is shallow, as government-conducted policies dominate climate change and RES management issues.

Climate change generally influences the communities lagging behind more seriously, as poverty environment traps make their population more vulnerable. Overall state interventions such as general price subsidies can help richer social groups to a greater extent, supporting their extra energy consumption. A more specialized, locally bounded energy support method may reduce poverty [45]. The recent Hungarian centralized energy support scheme, on the one hand, takes no notice of energy poverty, and on the other hand, does not incentivize energy conservation. In the target area, the smaller villages seem to be more vulnerable from an economic, demographic, and infrastructural point of view. Vulnerability is even more serious among the members of the poorer Roma minorities.

Climate change governance should take place in a complex socio-technological regime with multiple connected spheres [5]. According to experiences in the cases of Hungarian municipalities, the sphere of direct political influence is the strongest. According to the experiences of respondent municipalities in the implementation of local RES and EE projects and climate management, ecologic, economic, and social issues only play a limited role. 
Putting answers to the framework of Scanu and Cloutier [5] - the climate governance analytical grid-it might be stated that, in case of bigger towns, basic functions run by municipalities are the ones that pull these projects. Some marks of enabling can be seen as well when, in some cases, local schools implement awareness-raising projects for the youth and the rest of the local population. In the case of Recsk-a small village - the effect of a former awareness program led by the local elementary school is that local inhabitants are relatively well-informed about climate change and renewable energy (a broad questionnaire research was taken in every settlement among local inhabitants and the results will be presented in another paper). Municipalities frequently realize projects initiated by the EU, but mainly national (and sometimes political) policy determines the details. A typical case is the disregard of wind energy. As government decree 253/1997 (XII. 20) has regulated, only maximum 2 MW output power plants can be installed with less than $100 \mathrm{~m}$ height, and the distance from residential areas must be at least $12 \mathrm{~km}$. This quasi-banning of bigger wind power plants made smaller ones less popular as well.

Regarding European policy-making, municipalities should play multiple and relevant roles in the formation of climate and renewable governance processes [46,47]. The current experience is that Hungarian local municipalities are unable to develop their own climate and energy policies independent from the national government.

Both examined counties belong to the areas of Hungary that are socio-economically lagging behind, where socio-technological regimes related to climate change and RES harvest management prevail in a distorted form. Technology is taken from outside, mainly from global producers and distributors. Policy is dominated by macro-regional (EU climate issues) or national actors. Universities might play a crucial role in these processes in many dimensions (technology, planning, human resources), but, unfortunately, flourishing cooperation between local municipalities and institutions of higher education could not be identified. Smaller villages having disadvantageous groups (elderly persons, Roma minorities) are in a much more vulnerable situation. This trend conforms with the global injustice of climate change, where urban zones have the main responsibility for it, but rural areas suffer most because of their socio-economic backwardness [48]. Additionally, recently, the Hungarian energy market has been highly influenced by the state through legislation aimed at "overhead reduction", and consequently neither users nor market regards prevail.

As the literature states, the local level has a relevant role in climate change adaptation and mitigation issues $[4,38,49,50]$. As members of the Hungarian local upper-class have distorted concepts of RES, further awareness-raising and teaching activities should be done, even for members of the elite. Despite some local leaders being aware of the dangers of climate change and the fact that they usually refer to it in public speech, in practice, it is treated as something "out there" without any local responsibilities or tasks to do. In the target area, among previously implemented municipality-level projects, energy efficiency issues were in the majority. Mitigation seems to be the main objective locally, and, at the same time, adaptation measures are rare.

According to both the literature [50-52] and national strategic documents [53], public sector examples should be triggering factors for private persons. Respondents claimed that this is an overstatement, as the majority of local persons are not rich enough to implement any such projects. This may explain the low level of climate and energy governance and the poor utilization of local specialties. Local actors cannot play much of a role in the planning and the implementation of such programs. Usually, there are no municipality-level climate or RES strategies, and, in addition, former fruitful voluntary micro-regional co-operation was weakened by central political will. Instead of a mutually advantageous collaborative and autonomous attitude, a troubled atmosphere was created through national legislation and centrally disposed EU subsidies. This centralized contesting and politics-driven landscape made external political and intellectual groups dominant over local interests. The level of governance is generally low; consequently, local specialties are rarely integrated. The darkest side of the picture is the existence of an opaque network of advisory companies commissioning a remarkable portion of EU finances. 
Among these circumstances, local actors are not motivated to use their own resources and harvest their optimal mix of renewable energy sources.

\section{Conclusions}

The Hungarian spatial governance system is dominated by the central government. Local actors can hardly vindicate local interests. Climate change management policy has been centralized as well. Consequently, local interests, specialties, and resources often remain latent. On the one hand, this trend is completely at odds with the principles and the objectives of pertinent EU policies; on the other hand, it jeopardizes the fulfillment of mitigation and adaptation objectives. This system wastes resources, shows signs of malfunction, and estranges local actors from cooperation. Because of the lack of adequate financial resources, in general, local communities and inhabitants are unable to copy centrally tailored RES and EE projects and programs. Smaller villages and poorer people are in the least advantageous positions, as they owe neither knowledge nor resources.

The majority of finance in development in Hungary comes from the EU. Consequently, the national policy could be influenced. During the next EU programming period, the reconsideration of EU financial support related to climate change management is a must. Local, bottom-up initiatives must have a priority, and an emphasis should be put on participatory, community-led, and asset-based local development. Any financial support from EU sources should be attached to the existence of multi-level governance, as it may release local resources and ideas. This can help the realization of a more successful, integral, and sustainable climate management activity.

Author Contributions: Conceptualization, E.K., P.C., I.F. and G.S.; Methodology, C.P., Z.R. and T.T.; Investigation, E.K. and Z.R.; Resources, C.P. and Z.R.; Writing-Original Draft Preparation, C.P., J.B.T. and Z.R.; Visualization, J.B.T.; Supervision, P.C.; Project Administration, T.T.; Funding Acquisition, T.T.

Funding: This research was funded by the Hungarian National Research, Development and Innovation Office-NKFIH, grant number K 116595.

Conflicts of Interest: The authors declare no conflict of interest.

\section{Appendix A}

\section{Interview Guide}

A research project guided by the University of Debrecen and Eszterházy Károly University, Eger aims to study the social acceptance of renewable energy sources and opinions about climate change. The target group consists of municipality leaders (mayors, notaries), NGO executives, and school directors. As it was already indicated in a phone call, we would like to ask you for help in it for a maximum $90 \mathrm{~min}$ long in-depth interview.

Important: Your answers will be presented in an anonym form in articles or conference presentations. Sound recordings will not be publicized; only research staff will use them to refine the written field remarks. The written report about this interview will be sent to you for reading and reflecting.

\section{Introduction}

Please, introduce yourself (age, education, career, etc.) and tell us some important details about your village/town!

II. Climate change and renewable energy

Is there an energetic/climate change program/concept in your village/town? Do you know the climate management strategy of your county? Did you express your opinion during the preparation?

What are/would be the key points of a local climate change strategy?

What kind of renewable energies could you specify? 
Please, evaluate opportunities of renewable energy harvest globally/nationally/locally!

Were there any development projects in your village/town recently or in the recent past in the field of energy efficiency or renewable energy?

What type of technologies were they focusing on? What types should be used in the future? Why?

Who inspired these decisions? Who gave information supporting decision-making?

What were the main obstacles of these projects? How can these problems be fixed?

Were external financial resources used in these projects? What kind of finances were applied?

What were the main local benefits of these developments?

Which local interest groups were involved in the projects?

Were there joint actions with neighboring settlements to fight climate change or to use renewables?

Do you owe specialized knowledge related to climate change/renewable energies/energy efficiency?

What type of experts are relevant in the realization of such projects/programs? Is this expertise available locally?

Is there a local need to have such an educational program available for interested people?

Are local political leaders/economic actors/members of NGOs committed to fight climate change/to use renewable energy? How about the broader local public?

Are rising energy prices threatening the fulfillment of local public functions (economy, traffic, health, education, etc.)? To what extent can renewable energy help to solve this problem? To what extent are these projects expensive?

Can they help in increasing local tax sources/local job opportunities/settlement image/environment protection?

To what extent are financial resources available to fight climate change?

Beyond local municipality, what kind of other actors (inhabitants, NGOs, enterprises, state) invest in renewable energies? What type of energies are harvested?

Were there any awareness-raising campaigns to inform the public about climate change/renewable energy use? Are local inhabitants interested in these?

III. Plans for future development

Are there plans in your organization/municipality to start up energy efficiency or renewable energy harvest programs or projects in the near future?

Are there some plans to fight climate change/use renewable energy together with neighboring villages/towns?

\section{Closure}

Who else should be asked in your village/town about this topic?

Thank you for the interview!

\section{References}

1. Vidal, J. Feted by Hollywood, city mayors take starring role in Paris climate talks. The Guardian, 7 December 2015; p. 22.

2. Sedlacek, S. The role of universities in fostering sustainable development at the regional level. J. Clean. Prod. 2013, 48, 74-84. [CrossRef]

3. Höppner, C.; Whitmarsh, L. Public engagement in climate action: Policy and public expectations. In Engaging the Public with Climate Change: Behaviour Change and Communication; Whitmarsh, L., O'Neill, S., Lorenzoni, I., Eds.; Earthscan: London, UK, 2010.

4. Measham, T.G.; Preston, B.L.; Smith, T.F.; Brooke, C.; Gorddard, R.; Withycombe, G.; Morrison, C. Adapting to climate change through local municipal planning: Barriers and challenges. Mitig. Adapt. Strat. Glob. Chang. 2011, 16, 889-909. [CrossRef]

5. Scanu, E.; Cloutier, G. Why do cities get involved in climate governance? Insights from Canada and Italy. Urban Environ. 2015, 9. [CrossRef] 
6. Abbott, K. The Transnational Regime Complex for Climate Change. Environ. Plan. C Gov. Policy 2012, 30, 571-590. [CrossRef]

7. Fröhlich, J.; Knieling, J. Conceptualising climate change governance. In Climate Change Governance; Knieling, J., Leal Filho, W., Eds.; Springer-Verlag: Berlin/Heidelberg, Germany, 2013; pp. 9-26. [CrossRef]

8. Schwartz, E. Autonomous Local Climate Change Policy: An Analysis of the Effect of Intergovernmental Relations Among Subnational Governments. Rev. Policy Res. 2019, 36, 50-74. [CrossRef]

9. Adger, W.N.; Arnell, N.W.; Tompkins, E.L. Successful adaptation to climate change across scales. Glob. Environ. Chang. 2005, 15, 77-86. [CrossRef]

10. Sharp, E.; Daley, D.; Lynch, M. Understanding Local Adoption and Implementation of Climate Change Mitigation Policy. Urban Aff. Rev. 2011, 47, 433-457. [CrossRef]

11. Wang, X.; Liu, C.; Hawkins, C.V. Local Government Strategies for Financing Energy Efficiency Initiatives. Am. Rev. Public Adm. 2015, 47, 1-21. [CrossRef]

12. Enyedi, G. Regionális folyamatok a posztszocialista Magyarországon. Magyar Tudomány 2004, 9, 935-941.

13. Fodor, L.; Bányai, O. A Települési Önkormányzatok Szerepe a Környezeti Politika és Jog Alakításában; Dupress: Debrecen, Hungary, 2017.

14. Guha, R. Environmentalism. A Global History; Longman: New York, NY, USA, 2000.

15. Grin, J.; Schot, J.; Rotmans, J. Transitions to Sustainable Development: New Directions in the Study of Long Term Transformative Change; Routledge: New York, NY, USA, 2010.

16. Kivimaa, P.; Hildén, M.; Huitemac, D.; Jordan, A.; Newig, J. Experiments in climate governance-A systematic review of research on energy and built environment transitions. J. Clean. Prod. 2017, 169, 17-29. [CrossRef]

17. Schot, J.W.; Geels, F.W. Strategic niche management and sustainable innovation journeys: Theory, findings, research agenda and policy. Technol. Anal. Strateg. Manag. 2008, 20, 537-554. [CrossRef]

18. Anguelovski, I.; Carmin, J. Something Borrowed, Everything New: Innovation and Institutionalization in Urban Climate Governance. Curr. Opin. Environ. Sustain. 2011, 3, 169-175. [CrossRef]

19. Keskitalo, E.C.H.; Juhola, S.; Baron, N.; Fyhn, H.; Klein, J. Implementing local climate change adaptation and mitigation actions: The role of various policy instruments in a multi-level governance context. Climate 2016, 4, 7. [CrossRef]

20. Mondal, A.H.; Kamp, L.M.; Pachova, N.I. Drivers, barriers, and strategies for implementation of renewable energy technologies in rural areas in Bangladesh-An innovation system analysis. Energy Policy 2010, 38, 4626-4634. [CrossRef]

21. Freeman, C. Technology Policy and Economic Performance; Pinter: London, UK, 1987.

22. Malerba, F. Sectoral systems of innovation: A framework for linking innovation to the knowledge base, structure and dynamics of sectors. Econ. Innov. New Technol. 2005, 14, 63-82. [CrossRef]

23. Schumacher, E.F. Future is Manageable: Schumacher's Observations on Non-Violent Economics and Technology with a Human Face; Impex: New Delhi, India, 1978.

24. Geels, F.W. The multi-level perspective on sustainability transitions: Responses to seven criticisms. Environ. Innov. Soc. Transit. 2011, 1, 24-40. [CrossRef]

25. Elbe, S.; Elbe, J.; Meyer, W.; Albrecht, M. Networks are causing effects—But how?! Impact evaluation of networks. In Proceedings of the 10th Biennial EES Conference in Helsinki, Helsinki, Finland, 3-5 October 2012.

26. Hoppe, T.; de Vries, G. Social innovation and the energy transition. Sustainability 2018, 11, 141. [CrossRef]

27. Schönberger, P. Municipalities as Key Actors of German Renewable Energy Governance: An Analysis of Opportunities, Obstacles, and Multi-Level Influences. Wuppertal Papers, No. 186; Wuppertal Institut für Klima: Wuppertal, Germany, 2013.

28. Meadowcroft, J. Participation and sustainable development: Modes of citizen, community and organisational involvement. In Governance for Sustainable Development. The Challenge of Adapting Form to Function; Lafferty, W.M., Ed.; Edward Edgar Publishing: Cheltenham, UK, 2004; pp. 162-190. [CrossRef]

29. Portney, K.E. Taking Sustainable Cities Seriously: Economic Development, the Environment, and Quality of Life in American Cities; MIT Press: Cambridge, MA, USA, 2003; p. 312.

30. Lindseth, G. The cities for Climate Protection Campaign (CCPC) and the local environment. Local Environ. 2004, 9, 325-336. [CrossRef]

31. Kuttler, W. Climate change on the urban scale-Effects and counter-measures in Central Europe. In Human and Social Dimensions of Climate Change; Chhetri, N., Ed.; IntechOpen e-book: London, UK, 2012; pp. 105-142. [CrossRef] 
32. Krause, R. An Assessment of the Impact that Participation in Local Climate Networks Has on Cities' Implementation of Climate, Energy, and Transportation Policies. Rev. Policy Res. 2012, 29, 585-604. [CrossRef]

33. Betsill, M.; Bulkeley, H. Cities and the Multilevel Governance of Global Climate Change. Glob. Gov. 2006, 12, 141-159. [CrossRef]

34. Hakelberg, L. Governance by Diffusion: Transnational Municipal Networks and the Spread of Local Climate Strategies in Europe. Glob. Environ. Politics 2014, 14, 107-129. [CrossRef]

35. Toly, N.J. Transnational Municipal Networks in Climate Politics: From Global Governance to Global Politics. Globalizations 2008, 5, 341-356. [CrossRef]

36. Douglas, D. Governance in Rural Contexts: Toward the Formulation of a Conceptual Framework. EchoGéo 2018, 43. [CrossRef]

37. Robinson, P.; Gore, C. Barriers to Canadian municipal response to climate change. Can. J. Urban Res. 2005, $14,102-121$.

38. Amundsen, H.; Berglund, F.; Westskog, H. Overcoming Barriers to Climate Change Adaptation-A Question of Multilevel Governance? Environ. Plan. C Gov. Policy 2010, 28, 276-289. [CrossRef]

39. Wejs, A. Integrating climate change into governance at the municipal scale: An institutional perspective on practices in Denmark. Environ. Plan. C Gov. Policy 2014, 32, 1017-1035. [CrossRef]

40. Eckersley, P. Local Climate Governance in England and Germany: Converging Towards a Hybrid Model? PhD Thesis, School of Geography, Politics and Sociology Newcastle University, Newcastle, UK, 2016; p. 352.

41. EU Fraud Office Finds Irregularities in Projects Linked to Hungarian Leader's Son-in-Law. Available online: https://www.wsj.com/articles/eu-fraud-office-finds-irregularities-in-projects-linked-to-hungarianleaders-son-in-law-1515744340 (accessed on 12 March 2019).

42. Debrecen Megyei Jogú Város. Debrecen Megyei Jogú Város Smart City Stratégiája; EDC Debrecen Urban and Economic Development Center: Debrecen, Hungary, 2019.

43. Collins, K.; Ison, R. Jumping off Arnstein's ladder: Social learning as a new policy paradigm for climate change adaptation. Environ. Policy Gov. 2009, 19, 358-373. [CrossRef]

44. Agnew, J. Mapping political power beyond state boundaries: Territory, identity, and movement in world politics. Millennium 1999, 28, 499-521. [CrossRef]

45. Barbier, E.B.; Hochard, J.P. The impacts of climate change on the poor in disadvantaged regions. Rev. Environ. Econ. Policy 2018, 12, 26-47. [CrossRef]

46. Kern, K. Climate governance in the EU multi-level system: The role of cities. In Proceedings of the Fifth Pan-European Conference of EU Politics, Porto, Portugal, 23-26 June 2010.

47. Bartels, W.-L.; Furman, C.A.; Diehl, D.C.; Royce, F.S.; Dourte, D.R.; Ortiz, B.V.; Zierden, D.F.; Irani, T.A.; Fraisse, C.W.; Jones, J.W. Warming up to climate change: A participatory approach to engaging with agricultural stakeholders in the Southeast US. Reg. Environ. Chang. 2013, 13 (Suppl. 1), 45-55. [CrossRef]

48. Mearns, R.; Norton, A. Social Dimensions of Climate Change: Equity and Vulnerability in a Warming World; World Bank: Washington, DC, USA, 2010.

49. Bulkeley, H.; Kern, K. Local government and the governing of climate change in Germany and the UK. Urban Stud. 2006, 43, 2237-2259. [CrossRef]

50. Zheng, J.; Mehndiratta, S.; Guo, J.Y.; Liu, Z. Strategic policies and demonstration program of electric vehicle in China. Transp. Policy 2012, 19, 17-25. [CrossRef]

51. Skjølsvold, T.M.; Lindkvist, C. Ambivalence, designing users and user imaginaries in the European smart grid: Insights from an interdisciplinary demonstration project. Energy Res. Soc. Sci. 2015, 9, 43-50. [CrossRef]

52. Bossink, B.A.G. Demonstrating sustainable energy: A review based model of sustainable energy demonstration projects. Renew. Sustain. Energy Rev. 2017, 77, 1349-1362. [CrossRef]

53. Nemzeti Fejlesztési Minisztérium. Magyarország Nemzeti Energiahatékonysági Cselekvési Terve 2020-ig Az Európai Parlament és Tanács 2012/27/EU Irányelve az Energiahatékonyságról (EED) 24. Cikk (2) Bekezdésében Előirt Beszámolási Kötelezettség; Nemzeti Fejlesztési Minisztérium: Budapest, Hungary, 2015; Available online: https://www.kormany.hu/download/1/25/80000/IIINemzeti\%20Energiahat\%C3\%A9konys\%C3\% A1gi\%20Cselekv\%C3\%A9si\%20Terv_HU.PDF (accessed on 18 May 2019).

(C) 2019 by the authors. Licensee MDPI, Basel, Switzerland. This article is an open access article distributed under the terms and conditions of the Creative Commons Attribution (CC BY) license (http://creativecommons.org/licenses/by/4.0/). 